\title{
Quality changes during frozen storage of blue shrimp (Litopenaeus stylirostris) with antioxidant, $a$-tocopherol, under different conditions
}

\author{
Adriana Zulema VALENCIA-PEREZ ${ }^{1}$, Herlinda SOTO-VALDEZ ${ }^{2}$, \\ Josafat Marina EZQUERRA-BRAUER ${ }^{1}$, Enrique MÁRQUEZ-RÍOS ${ }^{1}$, Wilfrido TORRES-ARREOLA ${ }^{1 *}$
}

\begin{abstract}
Fresh blue shrimp (Litopenaeus stylirostris) muscle was stored with antioxidants under different conditions: ANTIOX 2\%, packed in bilayer film of polyamide-low density polyethylene film (PA-LDPE) with $2 \%$ a-tocopherol; ANTIOX $4 \%$, packed in PA-LDPE film with $4 \%$-tocopherol; and ANTIOX-GLAZED, samples stored glazed with $2 \% \alpha$-tocopherol. Shrimps packed in PA-LDPE without $\alpha$-tocopherol were used as CONTROL. All samples were stored at $-20^{\circ} \mathrm{C}$ for 120 days. As compared to the CONTROL, the shrimp stored with the antioxidant showed lower lipid oxidation (0.10-0.14 vs $1.58 \mathrm{mgMA} / \mathrm{kg}$ of muscle), lost less firmness and astaxanthin content. ANTIOX $2 \%$ and ANTIOX-GLAZED showed the lowest concentrations of formaldehyde $(0.081-0.083 \mu \mathrm{M} / \mathrm{g})$. There were no significant differences in color and sensory properties, but differences in the integrity of the muscle fibers were observed. The treatments with $\alpha$-tocopherol maintained the shrimp muscle quality during frozen storage. However, no significant differences were found between these treatments.
\end{abstract}

Keywords: Litopenaeus stylirostris; a-tocopherol; lipid oxidation; freezing; quality.

Practical Application: Development of methods for quality preservation of seafood products during cold storage.

\section{Introduction}

Shrimp is one of the most important seafood products worldwide (Oosterveer, 2006). Litopenaeus stylirostris is widely commercialized, and it can be obtained either from an aquaculture or wild. When frozen, it can increase its commercial value due to its chemical and sensory stability. However, some chemical and biochemical reactions can occur even at frozen temperatures (Fennema et al., 2008), including oxidative changes of lipids and proteins in the muscle, which can affect deterioration in the organoleptic and sensory quality of the product, such as odor, rancidity, dehydration, weight loss, color, and texture (Tsironi et al., 2009).

For the reasons mentioned above, freezing is insufficient to ensure preservation of quality of shrimp after catch or during post-harvest handling; therefore, the use of alternative technologies, such as the addition of antioxidant (natural or synthetic) compounds, is necessary. Its use in marine products has been evaluated primarily in fish oils and/or by direct addition to the muscle during glazing (Tang et al., 2001). However, one disadvantage of this technique is that the migration of the antioxidant to the muscle is not controlled. Thus, a practicable alternative is the use of plastic packaging containing antioxidants, which may retard lipid oxidation and protein denaturation under a controlled release of the antioxidants (Torres-Arreola et al., 2007).

Several studies have been conducted on the incorporation of BHT in polyethylene films which showed capacity of retarding lipid oxidation in muscle (Huang \& Weng., 1998; Torres-Arreola et al, 2007; Soto-Valdez et al., 2015). Nevertheless, the use of synthetic antioxidants in foods is restricted in many countries due to their harmful effects on consumer health (Hraš et al., 2000). Consequently, the evaluation of natural antioxidants and their potential use during post-harvest or post-catch handling of marine organisms is necessary.

a-tocopherol is one of the major natural compounds used as an antioxidant by the food industry that is safe and provides multiple health benefits (López de Dicastillo et al., 2012). Granda-Restrepo et al. (2009) developed a polyethylene plastic film with $a$-tocopherol measuring its migration to the milk powder during storage at 20,30 and $40^{\circ} \mathrm{C}$. Nonetheless, it is necessary to evaluate its effectiveness in foods with high moisture content at frozen temperatures, such as muscle of marine organisms. Therefore, the present study focuses on the potential application of plastic films containing $\alpha$-tocopherol as a natural antioxidant and evaluates its effects on the changes in quality in blue shrimp (Litopenaeus stylirostris) muscle during frozen storage.

\section{Materials and methods}

\subsection{Antioxidant packaging films}

Two and $4 \%$ of $\alpha$-tocopherol were co-extruded with Low density Polyethylene (LDPE, inner layer) and polyamide (PA, outer layer) with $7 \%$ of $\mathrm{TiO}_{2}$ by the blow extrusion process using a pilot-plant size co-extruder (Beutelspacher, México D.F., México) 
at the Centro de Investigación en Alimentación y Desarrollo, A.C. campus Hermosillo, México. A control LDPE-PA film without antioxidants was also manufactured. Polyolefin was used to adhere the 2 layers. Three films were manufactured: ANTIOX $2 \%$ film (LDPE $+\mathrm{TiO}_{2} / \mathrm{PA}+2 \%$ a-tocopherol); ANTIOX $4 \%$ film (LDPE $+\mathrm{TiO}_{2} / \mathrm{PA}+4 \%$ a-tocopherol); and CONTROL film (LDPE $+\mathrm{TiO}_{2} / \mathrm{PA}$ ). Finally, a glaze was obtained using an $\alpha$-tocopherol emulsion in water, with a concentration of $2 \mathrm{~g}$ of the antioxidant $/ 100 \mathrm{~mL}$. All reagents were purchased from Sigma (USA).

\subsection{Sampling}

Wild blue shrimp (Litopenaeus stylirostris) used in this study were captured in the Gulf of California, Mexico $\left(28.75^{\circ} \mathrm{N} / 112.25^{\circ} \mathrm{W}\right)$, during the fall season and transported on ice to the seafood laboratory at the University of Sonora within $6 \mathrm{~h}$ of capture (postrigor state). The headless shrimp (muscle) with weight of 15-18 g was packed under different conditions and stored at $-20 \pm 2{ }^{\circ} \mathrm{C}$ for 120 days. Samples for analytical determinations were taken on days 0,60 , and 120 .

\subsection{Chemical analysis}

Thiobarbituric Acid Index (TBA-i)

TBA-i during frozen storage (120 days) was determined using $10 \mathrm{~g}$ of muscle colorimetrically at $538 \mathrm{~nm}$. A standard curve was constructed with 1,1,3,3-tetraethoxypropane (Woywwoda et al., 1986). The TBA-i was reported as mg malonaldehyde/kg muscle.

\section{Astaxantine content}

The content of astaxanthin was determined as index of total carotenoids, according to the modified method of Sachindra et al. (2005). Shrimp sample (25 g) was extracted with $100 \mathrm{ml}$ of acetone using a tissue homogenizer M133/ 1281 (Biospec Products, Bartlesville, OK) for 2 min. After extraction, the samples were transferred to a $500 \mathrm{ml}$ separatory funnel containing $100 \mathrm{ml}$ of petroleum ether. The petroleum extracts were then mixed with distilled water containing $1 \%(\mathrm{w} / \mathrm{v})$ sodium chloride. Finally, the absorption spectrum of the water insoluble compounds was recorded at $472 \mathrm{~nm}$ using a UV spectrophotometer (Cary 50; Varian, Walnut Creek, CA, USA). Calculation of the astaxanthin concentration was performed using the standard curve of astaxanthin.

\section{Production of formaldehyde}

The formaldehyde content in the blue shrimp muscle during frozen storage was monitored according to Woyewoda et al. (1986) using $100 \mathrm{~g}$ of tissue with colorimetric detection at $415 \mathrm{~nm}$ and a UV spectrophotometer (Cary 50; Varian, Walnut Creek, CA, USA). The standard curve was constructed using a $0.074 \%$ formaldehyde solution. The results were reported as $\mathrm{mg}$ formaldehyde /g muscle.

\subsection{Physical analysis}

Texture

Ten samples of fresh (0-day) and frozen fish in contact with ANTIOX $2 \%$ or ANTIOX $4 \%$ films were subjected to texture analysis and compared to the CONTROL and ANTIOX-GLAZED samples. Texture was measured by recording the force required to penetrate the material using a Chatillon 2-3b texturometer with a cylindrical plunger of $0.6 \mathrm{~cm}$ diameter. Each sample (second and third segment of the muscle) was placed in a position relative to the cylindrical plunger that would result in shearing across the muscle fiber (Dunajski, 1980).

\section{Color measurement}

The frozen shrimp samples were thawed in a refrigerator and cooked in water at $100^{\circ} \mathrm{C}$ for $8 \mathrm{~min}$. Color was measured using a colorimeter (Minolta CR-300). For each sample, at least five measurements were performed at different positions of the sample, and the measured values were compared with those of the same sample prior to storage. The average values of 10 samples were reported.

\section{Scanning electron microscopy}

Scanning electron microscopy was carried out according to Plascencia-Jatomea et al. (2003). Shrimp muscles $(0.5 \times 0.5 \mathrm{~cm})$ were fixed by immersion in $5 \%(\mathrm{v} / \mathrm{v})$ glutaraldehyde for $24 \mathrm{~h}$ at $4^{\circ} \mathrm{C}$ and post-fixed with $1 \%(\mathrm{w} / \mathrm{v})$ osmium tetroxide for $2 \mathrm{~h}$ at $4^{\circ} \mathrm{C}$. The fixed samples were dehydrated in a graded acetone series and coated with carbon and gold prior to examination in a Scanning Electron Microscope (JEOL JSM-5410 LV).

\subsection{Sensory analysis}

The frozen shrimp were cooked and evaluated by 20 untrained panelists using a 10-point hedonic scale ranging from $10=$ like extremely to $1=$ dislike extremely (Dorado-Rodelo et al., 2007). All panelists were asked to evaluate overall likeness, texture and flavor. Unpeeled samples were presented to the panelists in plates coded with three-digit random numbers.

\subsection{Statistical analysis}

A completely randomized design (two-way ANOVA) was carried out using the type of film (four levels) and storage time (three levels) as factors. Ten different samples of each different storage time treatment were used for texture and color. Five samples were used in the rest of the determinations. Tukey's test, at level of significance $p<0.05$, was used to determine differences between the treatments of every storage time using the JMP 5.00 software (Statsoft, Tulsa, OK). A nonparametric analysis with a Kruskal-Wallis test was carried out for sensory analysis. 


\section{Results and discussion}

\subsection{Chemical analysis}

\section{Thiobarbituric Acid Index (TBA-i)}

The lipid content in shrimp samples is relatively low compared with that of fatty fish such as sardines or sierra (Heu et al., 2003; Sriket et al., 2007). However, changes in lipid structure and behavior could be responsible for the deterioration of muscle quality during frozen storage (Sikorski \& Kołakowska, 1995). Table 1 shows changes in TBA-i (quality index) of blue shrimp muscle during frozen storage. No values of TBA-i were detected in fresh muscle, result that was observed in all treatments for the first 90 days. However, after 120 days, shrimp stored without antioxidant (CONTROL) showed $1.58 \mathrm{mgMA} / \mathrm{kg}$ of muscle, whereas such increase was not observed in the samples stored with ANTIOX-GLAZED, ANTIOX 2\% and ANTIOX 4\%. This suggests that after this storage period, the different antioxidant concentrations used successfully prevented lipid oxidation.

These results are in accordance with those reported for several species of crustaceans, which have not exceeded $5 \mathrm{mgMA} / \mathrm{kg}$ of muscle in samples that were both stored under ice and frozen (Cadun, et al., 2005; Calder et al., 2005; Kong et al., 2006; Tseng et al., 2005). On the other hand, Bak et al. (1999) found a significant increase in lipid oxidation of cooked cold-water shrimp (Pandalus borealis) after sixth months of frozen storage with atmospheric air, while the shrimp packaged in modified atmospheres showed no significant differences after the same period. Moreover, Tseng et al. (2005) found no differences in TBARS of Australian river crab (Cherax quadricarinatus) treated with propyl gallate, $\alpha$-tocopherol and rosemary extract as antioxidant solutions over the storage period of three months. This indicates that crustacean muscles are not susceptible to lipid oxidation during frozen storage, probably due to their carotenoids content which could prevent these lipid changes, acting as antioxidants (Shahidi et al., 1998).

\section{Total carotenoids content}

Astaxanthin is the main carotenoid reported in shrimp muscle, which is found to vary between 64 and $98 \%$ of the total carotenoids (Goodwin, 1984; Latscha, 1989). Because of this, its quantification can be considered as an index of total carotenoids in shrimp muscle. Figure 1 shows changes in the astaxanthin content of blue shrimp muscle subjected to all treatments during frozen storage with an initial value (fresh muscle) of about $20 \mu \mathrm{g} / \mathrm{g}$ muscle, which is in accordance with that reported for other species of shrimp (Sachindra et al., 2005); nevertheless, it tended to decrease significantly $(\mathrm{p}<0.05)$ in all samples after 120 days of storage. On the other hand, shrimp stored with CONTROL and ANTIOX-GLAZED showed an increase of 25 and 75 , respectively, after 60 days with a subsequent decrease $(\mathrm{p}<0.05)$. This behavior could be related to TBA-i values detected after the same period, where a decrease in astaxanthin concentration reflects an increase in malonaldehyde content. Accordingly, it is important to mention that due to the large number of conjugated double bonds in their structure, carotenoid compounds can act as antioxidants (Shahidi et al., 1998).
Table 1. Thiobarbituric acid index (TBA-i) in blue shrimp (Litopenaeus stylirostris) muscle after 120 days of frozen storage.

\begin{tabular}{cc}
\hline Treatment & TBA-i (mgMA/kg sample) \\
\hline CONTROL & $1.58 \pm 0.1^{\mathrm{a}}$ \\
ANTIOX-GLAZED & $0.14 \pm 0.03^{\mathrm{b}}$ \\
ANTIOX 2\% & $0.14 \pm 0.05^{\mathrm{b}}$ \\
ANTIOX 4\% & $0.10 \pm 0.03^{\mathrm{b}}$ \\
\hline
\end{tabular}

Results represent an average of 5 determinations. Different letters in the same column indicate significant differences $(\mathrm{P}<0.05)$ between the treatments.

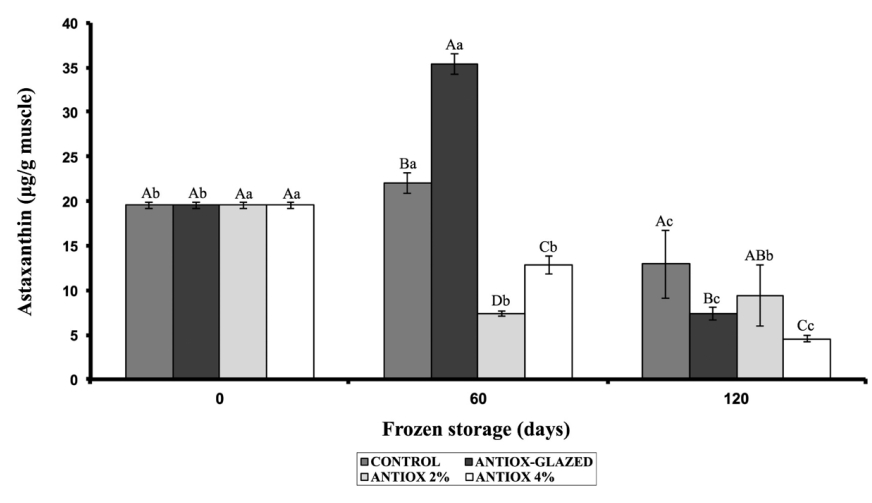

Figure 1. Astaxanthin content in blue shrimp (Litopenaeus stylirostris) muscle during frozen storage. Different capital letters in the same storage time indicate significant differences $(p<0.05)$ between the treatments. Different low-case letters in the same treatment indicate significant differences $(\mathrm{p}<0.05)$ throughout the storage time period. Results represent an average of 10 determinations.

As a result, according to the behavior explained above, the carotenoids in shrimp muscle acted as antioxidants between the second and fourth month of storage. Bak et al. (1999), detected significant losses in carotenoid content after three months of frozen storage of Pandalus borealis, showing a significant increase in TBA-i after sixth months. These results were attributed to the protective effect of astaxanthin against lipid oxidation.

\section{Production of formaldehyde}

Figure 2 shows the formaldehyde content in blue shrimp muscle during frozen storage. There was a significant increase $(\mathrm{P}<0.05)$ in the CONTROL treatment after 60 days, and it kept increasing constantly throughout the whole experiment period. On the other hand, the ANTIOX-GLAZED, ANTIOX 2\%, and ANTIOX 4\% treatments showed an increase in the formaldehyde levels up to 120 days of storage, remaining unchanged $(p \geq 0.05)$ during the first two months. Additionally, between the $\alpha$-tocopherol based treatments, ANTIOX 4\% and the CONTROL were the ones that reached the highest levels of formaldehyde, with no significant differences between them $(\mathrm{P} \geq 0.05)$, and therefore, it can be said that the ANTIOX 2\% and ANTIOX-GLAZED are the most effective in avoiding formaldehyde production in blue shrimp muscle after 4 months of storage at $-20^{\circ} \mathrm{C}$.

Production of formaldehyde in shrimp due to the enzymatic reduction of trimethylamine oxide (TMAO) is used as a quality index during post-mortem handling (Badii \& Howell, 2002). 
This compound accumulates during frozen storage, and it can react with the proteins in the muscle to denature them, thus causing changes in texture (Bianchi et al., 2007; Sotelo et al., 1995). Moreover, it has been reported that texture changes in the muscle of marine organisms during frozen storage can be related to interactions between the formaldehyde generated and proteins present (Matsumoto, 1979, cited by Bak et al., 1999), which was observed in the present study by comparing the results of formaldehyde production and texture profile, with a direct relation, especially in the CONTROL treatment (Figures 2 and 3). In other words, the presence of formaldehyde in blue shrimp leads to the softening of the muscle tissue.

\subsection{Physical analysis}

\section{Texture}

Firmness values of blue shrimp muscle during frozen storage are shown in Figure 3. There was a gradual decrease in the CONTROL treatment after 120 days $(\mathrm{p}<0.05)$, whereas samples stored with ANTIOX-GLAZED and ANTIOX 4\% had no significant changes in texture compared to that of the fresh muscle after 60 days. However, after 120 days of storage at $-20^{\circ} \mathrm{C}$, these samples exhibited a significant decrease in firmness $(\mathrm{p}<0.05)$. On the other hand, shrimp muscle packed and stored with ANTIOX $2 \%$ had no significant changes in texture $(\mathrm{p}<0.05)$ during the whole experiment period. This suggests that during at least two months at $-20^{\circ} \mathrm{C}$ all treatments with antioxidants prevent muscle softening in shrimp, and ANTIOX $2 \%$ was able to maintain the muscle fiber structure for a longer period at $-20^{\circ} \mathrm{C}$. This indicates that the magnitude of the "protective" effect of ANTIOX 2\% could be higher than that of the ANTIOX 4\% and ANTIOX-GLAZED. Nevertheless, these differences were not observed between the treatments after 120 days ( $\mathrm{p} \geq 0.05)$. On the other hand, the gradual decrease in firmness in the CONTROL treatment $(\mathrm{P}<0.05)$ suggests protective effect of the antioxidant treatments on the integrity of shrimp muscle since all treatments with antioxidant also prevented lipid oxidation after four months of storage (Table 1). This is based on the following statement: lipid oxidation produces free radicals, which are transferred to the amino acids and proteins and may cause its denaturation (Bak et al., 1999) leading to texture changes in the muscle (Undeland \& Lingnert, 1999).

Torres-Arreola et al. (2007) reported a protective effect of a low-density polyethylene with butylated hydroxytoluene on the integrity of lipids and texture in the Pacific Sierra (Scomberomorus sierra) after frozen storage during three months. Moreover, Tseng et al. (2005) found no loss in shear force of Cherax quadricarinatus muscle during frozen storage with antioxidant for three months. These findings are consistent with the results obtained in this study; the texture of muscle of marine organisms is influenced by the use of antioxidants.

\section{Changes in color}

Acceptance of frozen shrimp depends on its color, which is considered one of the most important sensory attributes (Niamnuy et al., 2008). Table 2 shows changes in color (value a, hue angle, and chroma) in blue shrimp muscle during storage

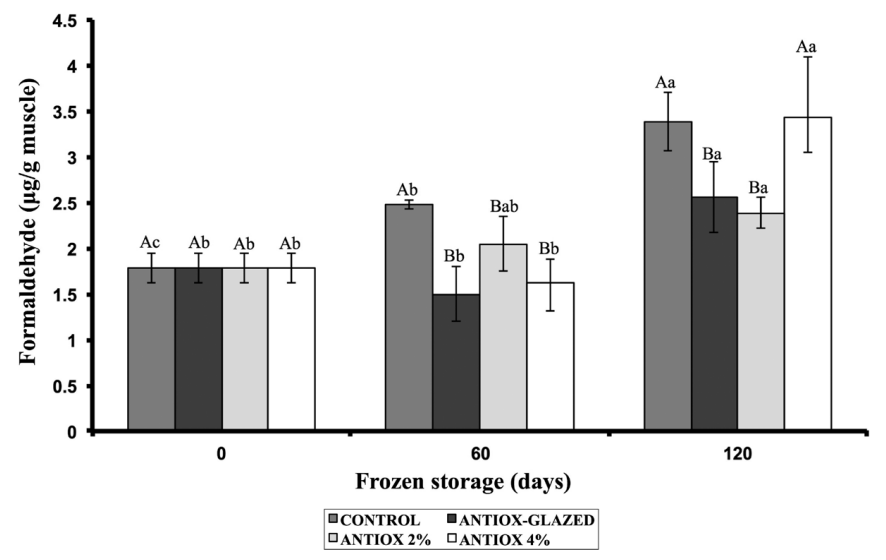

Figure 2. Changes in the formaldehyde concentration in blue shrimp (Litopenaeus stylirostris) muscle during frozen storage. Different capital letters in the same storage time indicate significant differences $(\mathrm{p}<0.05)$ between the treatments. Different low-case letters in the same treatment indicate significant differences $(\mathrm{p}<0.05)$ throughout the storage time period. Results represent an average of 10 determinations.

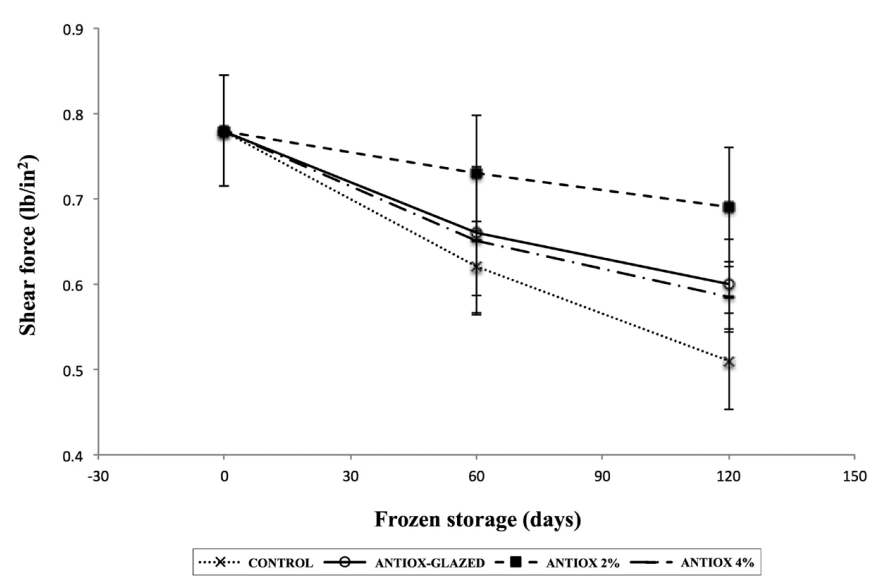

Figure 3. Texture of blue shrimp (Litopenaeus stylirostris) muscle during frozen storage. Results represent an average of the texture values obtained in 10 different samples.

at $-20^{\circ} \mathrm{C}$. It can be seen that there were no significant differences $(\mathrm{P} \geq 0.05)$ during the whole experiment period (120 days), contrasting with the results of the carotenoids analysis (Figure 1), which showed a decrease $(\mathrm{p}<0.05)$ in the astaxanthin content. Considering an association between color on crustaceans during cooking and carotenoid compounds, the effect on color in shrimp muscle could be expected. Significant effect of frozen storage on color in shrimp muscle has been reported; this result was found in shrimp subjected to cooking treatment prior to storage (Bak et al, 1999), whereas in the present study, cooking treatment was applied after storage.

\section{Scanning electron microscopy}

The micrographs of the blue shrimp muscle (Litopenaeus stylirostris) under different storage conditions are shown in Figure 4. The samples of all treatments (CONTROL, ANTIOX-GLAZED, 
Table 2. Value a, hue and chroma of the cooked muscle $\left(8 \mathrm{~min}\right.$ at $\left.100^{\circ} \mathrm{C}\right)$ of blue shrimp (Litopenaeus stylirostris) after four months of frozen storage.

\begin{tabular}{|c|c|c|c|c|c|c|c|c|c|c|c|c|}
\hline \multirow{2}{*}{$\begin{array}{c}\text { Frozen } \\
\text { storage } \\
\text { (Days) }\end{array}$} & \multicolumn{3}{|c|}{ CONTROL } & \multicolumn{3}{|c|}{ ANTIOX-GLAZED } & \multicolumn{3}{|c|}{ ANTIOX 2\% } & \multicolumn{3}{|c|}{ ANTIOX 4\% } \\
\hline & Value a & Hue angle & Chroma & Value a & Hue angle & Chroma & Value a & Hue angle & Chroma & Value a & Hue angle & Chroma \\
\hline $\mathbf{0}$ & $14.92 \pm 3.11^{\mathrm{a}}$ & $63.67 \pm 2.11^{\mathrm{a}}$ & $34.15 \pm 7.69^{\mathrm{a}}$ & $14.92 \pm 3.11^{\mathrm{a}}$ & $63.67 \pm 2.11^{\mathrm{a}}$ & $34.15 \pm 7.69^{\mathrm{a}}$ & $14.92 \pm 3.11^{\mathrm{a}}$ & $63.67 \pm 2.11^{a}$ & $34.15 \pm 7.69^{\mathrm{a}}$ & $14.92 \pm 3.11^{\mathrm{a}}$ & $63.67 \pm 2.11^{\mathrm{a}}$ & $34.15 \pm 7.69 \mathrm{a}$ \\
\hline 60 & $11.74 \pm 2.67^{\mathrm{a}}$ & $67.08 \pm 2.22^{\mathrm{a}}$ & $29.89 \pm 4.72^{\mathrm{a}}$ & $12.09 \pm 2.22^{\mathrm{a}}$ & $65.92 \pm 1.94^{\mathrm{a}}$ & $29.44 \pm 3.73^{\mathrm{a}}$ & $11.95 \pm 2.40^{\mathrm{a}}$ & $65.99 \pm 2.24^{\mathrm{a}}$ & $29.18 \pm 3.81^{\mathrm{a}}$ & $12.66 \pm 3.09^{\mathrm{a}}$ & $64.74 \pm 2.11^{\mathrm{a}}$ & $29.42 \pm 5.23^{\mathrm{a}}$ \\
\hline 120 & $12.86 \pm 2.41^{\mathrm{a}}$ & $65.08 \pm 2.08^{\mathrm{a}}$ & $30.40 \pm 4.22^{\mathrm{a}}$ & $13.21 \pm 3.18^{\mathrm{a}}$ & $65.58 \pm 2.50^{\mathrm{a}}$ & $31.62 \pm 4.79^{\mathrm{a}}$ & $12.76 \pm 3.65^{\mathrm{a}}$ & $65.92 \pm 3.11^{\mathrm{a}}$ & $30.80 \pm 5.28^{\mathrm{a}}$ & $12.53 \pm 3.75^{\mathrm{a}}$ & $66.30 \pm 3.43^{\mathrm{a}}$ & $31.33 \pm 4.25^{\mathrm{a}}$ \\
\hline
\end{tabular}

Results represent an average of 10 determinations. Same letters in the same column mean no significant differences ( $\mathrm{p} \geq 0.05)$ between the treatments.
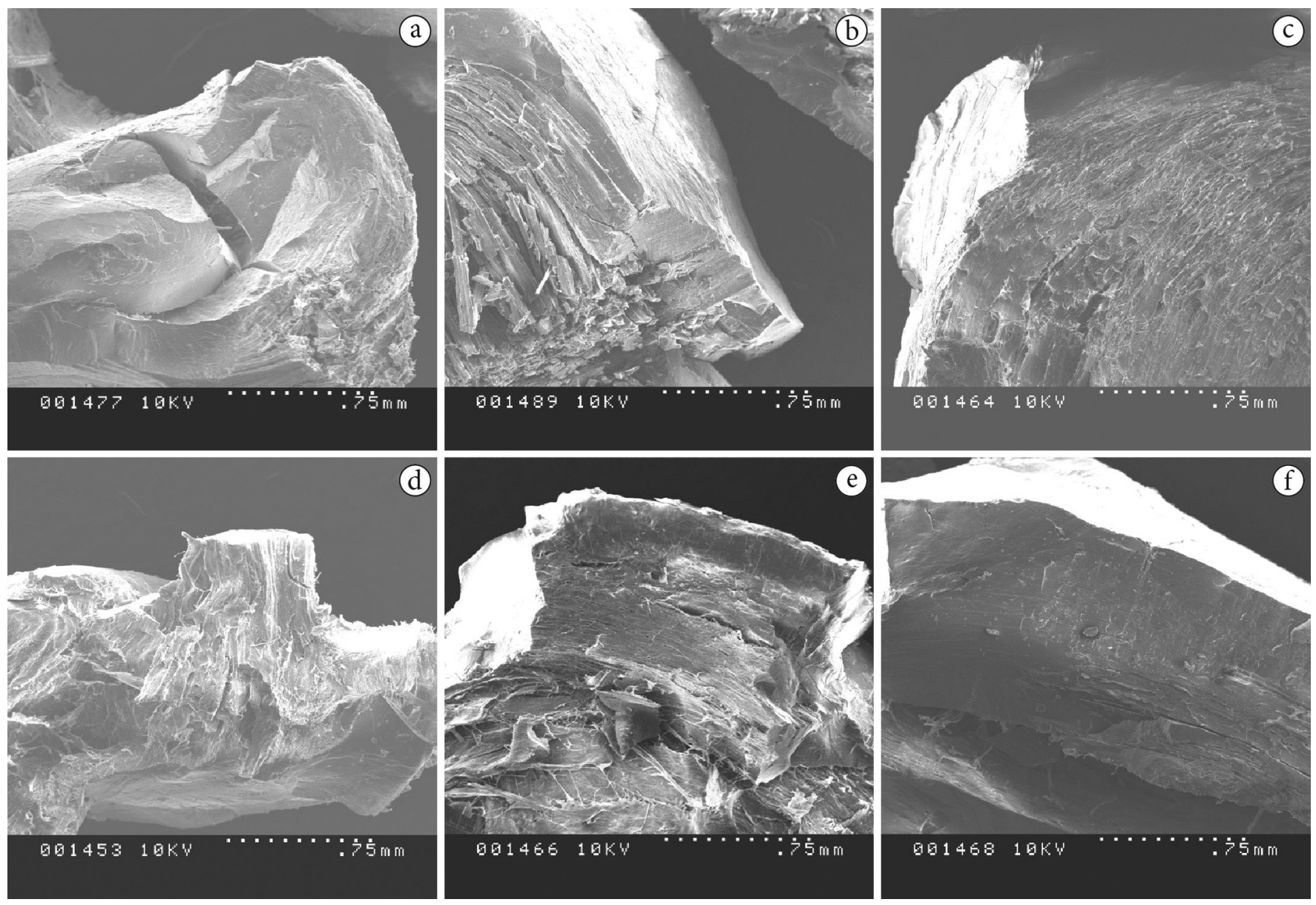

Figure 4. Micrographs of blue shrimp (Litopenaeus stylirostris) muscle. (a): fresh muscle; (b) fresh frozen muscle; (c): CONTROL after 4 months at $-20{ }^{\circ} \mathrm{C}$; (d) ANTIOX-GLAZED after 4 months at $-20{ }^{\circ} \mathrm{C}$; (e): ANTIOX $2 \%$ after 4 months at $-20{ }^{\circ} \mathrm{C}$; (f) ANTIOX $4 \%$ after 4 months at $-20{ }^{\circ} \mathrm{C}$.

ANTIOX $2 \%$, and ANTIOX $4 \%$ ), stored for 120 days at $-20^{\circ} \mathrm{C}$, were compared with fresh and fresh-frozen muscle samples, and the fibers of the two last ones showed tight contact with each other (Figure 4a-b). Some fractures can be observed in the muscle fibers of all samples stored with $a$-tocopherol (Figure $4 \mathrm{~d}-\mathrm{f}$ ), whereas in the CONTROL samples (Figure 4c), there was evident deformation. ANTIOX 4\% showed the best results in terms of maintaining muscle integrity after 120 days at $-20^{\circ} \mathrm{C}$ since it had a more compact and orderly distribution compared with that of the other treatments. Torres-Arreola et al. (2007) found that the use of LDPE films containing BHT as antioxidant prevents the fracture and detachment of sierra fish muscle during frozen storage showing an association between lipid oxidation and the integrity of the muscle fibers. However, in the present study, such behavior was not clearly observed since there was no high level of lipid oxidation present.

\subsection{Sensory analysis}

Figure 5 shows no significant differences $(\mathrm{p} \geq 0.05)$ in the flavor, color, and firmness of blue shrimp muscle samples stored under different conditions. On the other hand, instrumental analysis results (Figure 3 ) showed a different texture profile with a decrease in the shear force of the different samples evaluated. In this case, changes in firmness were not perceptible by senses. Sensory textural attributes have been evaluated in chilled lobster, and the results show that firmness was maintained after 10 days 

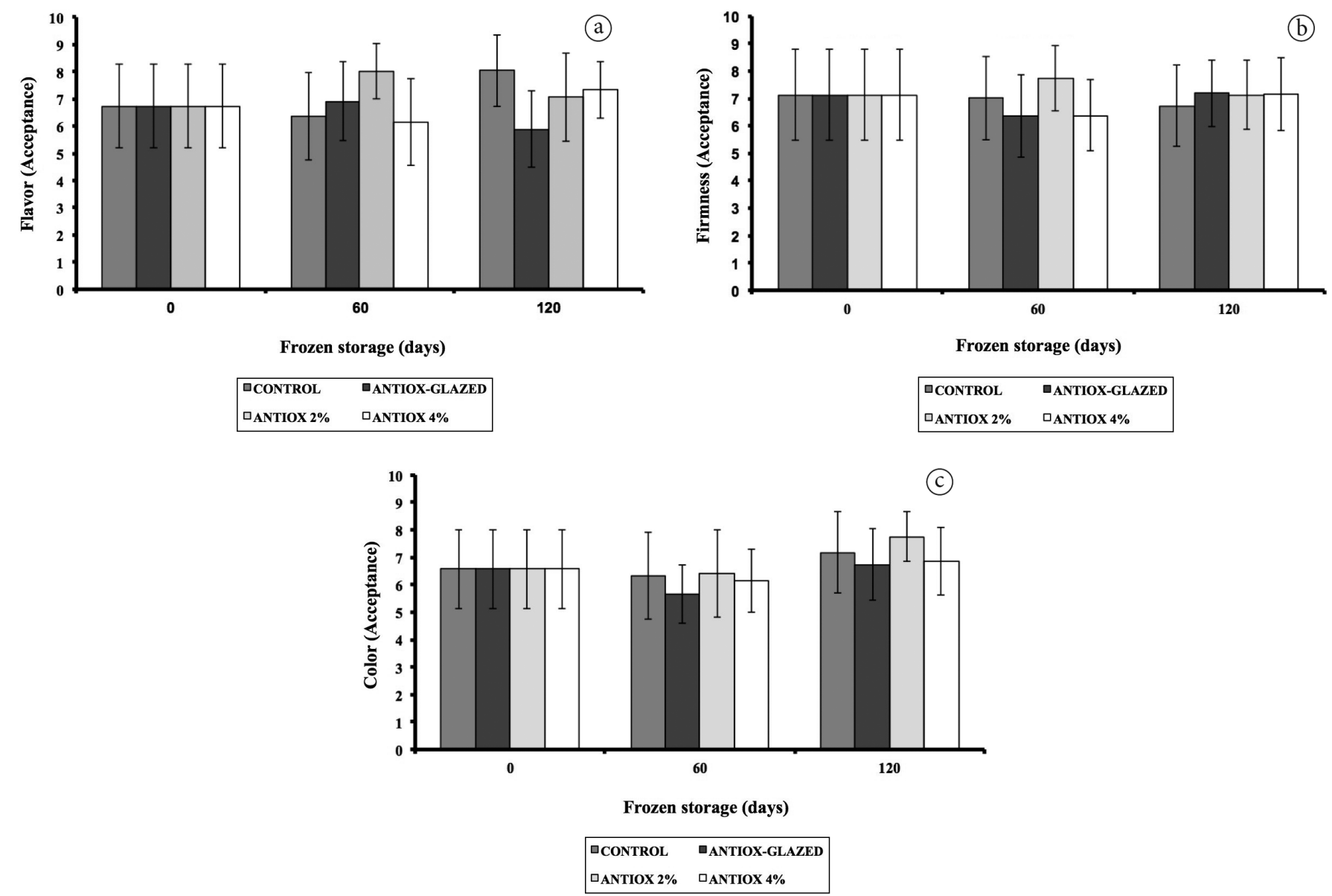

Figure 5. Sensory analysis of cooked $\left(8 \mathrm{~min}, 100^{\circ} \mathrm{C}\right.$ ) blue shrimp (Litopenaeus stylirostris) muscle after four months of frozen storage. Data represents the average values of the sensory evaluation performed by a panel of 20 untrained judges.

although significant differences in shear force were detected by instrumental techniques (Kong et al., 2006). Furthermore, Dorado-Rodelo et al. (2007) reported no significant differences in the attributes of flavor, firmness, and appearance of rose snapper fillets (Lutjanus guttatus) stored in ovenproof plastic films at $-20{ }^{\circ} \mathrm{C}$ for 120 days. Based on these results, it can be inferred that the levels of TBA-i and the formaldehyde concentration found in the shrimp muscle were not high enough to cause sensory changes.

\section{Conclusions}

It was possible to detect the protective effect of different treatments with $a$-tocopherol on oxidative changes in the blue shrimp muscle samples evaluated (TBA-i and total carotenoids) since there were no differences between them. Therefore, the antioxidant application method is irrelevant when evaluating its effect. Furthermore, the antioxidant used showed a protective effect on the fibers of shrimp muscle maintaining the integrity of its microstructure. Further studies are needed to evaluate the protective effect of $a$-tocopherol on the integrity of the proteins present in the blue shrimp muscle.

\section{Acknowledgements}

The authors gratefully acknowledge the assistance of Gabriel Francisco Leon Fontes in the preparation of the English version of this manuscript.

\section{References}

Badii, F., \& Howell, N. K. (2002). Effect of antioxidants, citrate, and cryoprotectants on protein denaturation and texture of frozen cod (Gadus morhua). Journal of Agricultural and Food Chemistry, 50(7), 2053-2061. http://dx.doi.org/10.1021/jf010824f. PMid:11902956.

Bak, L. S., Andersen, A. B., Andersen, E. M., \& Bertelsen, G. (1999). Effect of modified atmosphere packaging on oxidative changes in frozen stored cold water shrimp (Pandalus borealis). Food Chemistry, 64(2), 169-175. http://dx.doi.org/10.1016/S0308-8146(98)00152-6.

Bianchi, F., Careri, M., Musci, M., \& Mangia, A. (2007). Fish and food safety: determination of formaldehyde in 12 fish species by SPME extraction and GC-MS analysis. Food Chemistry, 100(3), 1049-1053. http://dx.doi.org/10.1016/j.foodchem.2005.09.089.

Cadun, A., Cakli, S., \& Kisla, D. (2005). A study of marination of deepwater pink shrimp (Parapenaeus longirostris, Lucas, 1846) and its shelf life. Food Chemistry, 90(1-2), 53-59. http://dx.doi. org/10.1016/j.foodchem.2004.03.024. 
Calder, B. L., Bushway, A. A., Bayer, R. C., Davis-Dentici, K. A., \& Camire, M. E. (2005). Quality of whole lobster (Homarus americanus) treated with sodium tripolyphosphate before cooking and frozen storage. Journal of Food Science, 70(9), C523-C528. http://dx.doi. org/10.1111/j.1365-2621.2005.tb08299.x.

Dorado-Rodelo, J. A., Ezquerra-Brauer, J. M., \& Soto-Valdez, H. (2007). Effect of ovenproof plastic films on the quality of spotted rose snapper (Lutjanus guttatus) fillets during frozen storage. Packaging Technology and Science, 20(5), 301-307. http://dx.doi.org/10.1002/pts.758.

Dunajski, E. (1980). Texture of fish muscle. Journal of Texture Studies, 10(4), 301-318. http://dx.doi.org/10.1111/j.1745-4603.1980.tb00862.x.

Fennema, O. R., Damodaran, S., \& Parkin, K. L. (Eds.). (2008). Fennema's food chemistry. Boca Raton: CRC Press.

Goodwin, T. W. (1984). The biochemistry of the carotenoids (Vol. 2, 184 p.). New York: Chapman and Hall.

Granda-Restrepo, D. M., Soto-Valdez, H., Peralta, E., Troncoso-Rojas, R., Vallejo-Córdoba, B., Gámez-Meza, N., \& Graciano-Verdugo, A. Z. (2009). Migration of $\alpha$-tocopherol from an active multilayer film into whole milk powder. Food Research International, 42(10), 13961402. http://dx.doi.org/10.1016/j.foodres.2009.07.007.

Heu, M. S., Kim, J. S., \& Shahidi, F. (2003). Components and nutritional quality of shrimp processing by-products. Food Chemistry, 82(2), 235-242. http://dx.doi.org/10.1016/S0308-8146(02)00519-8.

Hraš, A. R., Hadolin, M., Knez, Ž., \& Bauman, D. (2000). Comparison of antioxidative and synergistic effects of rosemary extract with a-tocopherol, ascorbyl palmitate and citric acid in sunflower oil. Food Chemistry, 71(2), 229-233. http://dx.doi.org/10.1016/S03088146(00)00161-8.

Huang, C. H., \& Weng, Y. M. (1998). Inhibition of lipid oxidation in fish muscle by antioxidant incorporated polyethylene film. Journal of Food Processing and Preservation, 22(3), 199-209. http://dx.doi. org/10.1111/j.1745-4549.1998.tb00345.x.

Kong, B., Xiong, Y. L., Fang, C., Thompson, K. R., Metts, L. S., Muzinic, L. A., \& Webster, C. D. (2006). Influence of gender and spawning on meat quality of Australian red claw crayfish (Cherax quadricarinatus) stored at 2 C. Journal of Food Science, 71(6), E320-E325. http:// dx.doi.org/10.1111/j.1750-3841.2006.00117.x.

Latscha, T. (1989). The role of astaxanthin in shrimp pigmentation. In Advances in Tropical Aquaculture Workshop at Tahiti, Tahiti, French Polynesia.

López-de-Dicastillo, C., Gómez-Estaca, J., Catalá, R., Gavara, R., \& Hernández-Muñoz, P. (2012). Active antioxidant packaging films: development and effect on lipid stability of brined sardines. Food Chemistry, 131(4), 1376-1384. http://dx.doi.org/10.1016/j. foodchem.2011.10.002.

Matsumoto, J. J. (1979). Denaturation of fish muscle proteins during frozen storage. In O. Fennema (Ed.), Proteins at low temperatures (Advances in Chemistry Series, Vol. 180, pp. 205-224). Washington: American Chemical Society.

Niamnuy, C., Devahastin, S., Soponronnarit, S., \& Vijaya Raghavan, G. S. (2008). Kinetics of astaxanthin degradation and color changes of dried shrimp during storage. Journal of Food Engineering, 87(4), 591-600. http://dx.doi.org/10.1016/j.jfoodeng.2008.01.013.

Oosterveer, P. (2006). Globalization and sustainable consumption of shrimp: consumers and governance in the global space of flows. International Journal of Consumer Studies, 30(5), 465-476. http:// dx.doi.org/10.1111/j.1470-6431.2006.00535.x.
Plascencia-Jatomea, M., Viniegra, G., Olayo, R., Castillo-Ortega, M. M., \& Shirai, K. (2003). Effect of chitosan and temperature on spore germination of Aspergillus niger. Macromolecular Bioscience, 3(10), 582-586. http://dx.doi.org/10.1002/mabi.200350024.

Sachindra, N. M., Bhaskar, N., \& Mahendrakar, N. S. (2005). Carotenoids in different body components of Indian shrimps. Journal of the Science of Food and Agriculture, 85(1), 167-172. http://dx.doi. org/10.1002/jsfa.1977.

Shahidi, F., Metusalach, \& Brown, J. A. (1998). Carotenoid pigments in seafoods and aquaculture. Critical Reviews in Food Science and Nutrition, 38(1), 1-67. http://dx.doi.org/10.1080/10408699891274165. PMid:9491309.

Sikorski, Z. E., \& Kołakowska, A. (1995). Changes in proteins in frozen stored fish. In Z. E., Sikorski, B. S., Pan, \& F., Shahidi (Eds.), Seafood proteins (pp. 99-112). New York: Springer US.

Sotelo, C. G., Piñeiro, C., \& Pérez-Martín, R. I. (1995). Denaturation of fish proteins during frozen storage: role of formaldehyde. Zeitschrift fur Lebensmittel-Untersuchung und-Forschung, 200(1), 14-23. http:// dx.doi.org/10.1007/BF01192902. PMid:7732729.

Soto-Valdez, H., Ezquerra-Brauer, J., Márquez-Ríos, E., \& TorresArreola, W. (2015). Effect of previous chilling storage on quality loss in frozen $\left(-20^{\circ} \mathrm{C}\right)$ sierra (Scomberomorus sierra) muscle packed with a low-density polyethylene film containing butylated hydroxytoluene. Food Science and Technology (Campinas.), 35(1), 202-206. http://dx.doi.org/10.1590/1678-457X.6607.

Sriket, P., Benjakul, S., Visessanguan, W., \& Kijroongrojana, K. (2007). Comparative studies on chemical composition and thermal properties of black tiger shrimp (Penaeus monodon) and white shrimp (Penaeus vannamei) meats. Food Chemistry, 103(4), 1199-1207. http://dx.doi. org/10.1016/j.foodchem.2006.10.039.

Tang, S., Sheehan, D., Buckley, D. J., Morrissey, P. A., \& Kerry, J. P. (2001). Anti-oxidant activity of added tea catechins on lipid oxidation of raw minced red meat, poultry and fish muscle. International Journal of Food Science \& Technology, 36(6), 685-692. http://dx.doi. org/10.1046/j.1365-2621.2001.00497.x.

Torres-Arreola, W., Soto-Valdez, H., Peralta, E., Cardenas-López, J. L., \& Ezquerra-Brauer, J. M. (2007). Effect of a low-density polyethylene film containing butylated hydroxytoluene on lipid oxidation and protein quality of Sierra fish (Scomberomorus sierra) muscle during frozen storage. Journal of Agricultural and Food Chemistry, 55(15), 6140-6146. http://dx.doi.org/10.1021/jf070418h. PMid:17595103.

Tseng, Y. C., Xiong, Y. L., \& Webster, C. D. (2005). The preservation of the quality of the muscle in frozen Australian red claw crayfish (Cherax quadricarinatus) by pre-storage anti-oxidant dipping treatments. International Journal of Food Science \& Technology, 40(8), 841-848. http://dx.doi.org/10.1111/j.1365-2621.2005.01004.x.

Tsironi, T., Dermesonlouoglou, E., Giannakourou, M., \& Taoukis, P. (2009). Shelf life modelling of frozen shrimp at variable temperature conditions. LWT-Food Science and Technology, 42(2), 664-671. http:// dx.doi.org/10.1016/j.lwt.2008.07.010.

Undeland, I., \& Lingnert, H. (1999). Lipid oxidation in fillets of herring (Clupea harengus) during frozen storage. Influence of prefreezing storage. Journal of Agricultural and Food Chemistry, 47(5), 2075-2081. http://dx.doi.org/10.1021/jf980944w. PMid:10552499.

Woyewoda, A. D., Shaw, S. J., Ke, P. J., \& Burns, B. G. (1986). Recommended Laboratory Methods for Assessment of Fish Quality (Canadian Technical Report of Fisheries and Aquatic Sciences, No. 1448). Canada: Nova Scotia. 